\title{
HAKIKAT ISI/MATERI PENDIDIKAN ISLAM
}

\section{Saadah Erliani ${ }^{1}$}

\section{Pendidikan Guru Sekolah Dasar STKIP PGRI Banjarmasin saadaherliani@stkipbjm.ac.id}

\begin{abstract}
ABSTRAK
Tujuan Hakikat isi atau materi pendidikan tidak terlepas dari filosofi manusia itu sendiri yang diciptakan oleh Allah. Setelah manusia diciptakan dan tinggal di surga, tetapi karena mengalami larangan dari Allah, sehingga manusia diturunkan di bumi. Berawal dari ini dan perjalanan sejarah manusia, bahwa manusia tidak terlepas dari pendidikan yang sumber utamanya adalah Alquran dan hadis. Seiring perubahan yang begitu drastis yang dialami manusia, maka pandangan terhadap pendidikan menjadi dua versi, yakni versi muslim dan Non muslim. Hasil artikel ini, memperoleh temuan penelitian; Pertama, hakikat manusia dan pendidikan mengalami dinamika sejarah perjalanan yang panjang sehingga kalangan Barat dan Muslim memberikan legitimasi masing-masing yang berbeda tentang manusia dan pendidikan. Kedua, hakikat isi materi pendidikan tidak terlepas dari kurikulum dan guru yang mengajarkannya kepada peserta didik. Guru mengalami tantangan yang begitu besar dari dampak perkembangan teknologi, sehingga kerja sama antara orang tua dan guru menjadi kunci keberhasilan dari pendidikan yang diberikan, walaupun masih terdapat hambatan bagi dunia pendidikan saat ini.
\end{abstract}

Kata Kunci: Hakikat Isi, Pendidikan Islam

\section{PENDAHULUAN}

Aktivitas pendidikan dalam Islam sudah mulai sejak adanya manusia itu sendiri. Bahkan, ayat yang pertama kali diturunkan kepada Nabi Muhammad saw, adalah iqra, yakni perintah "membaca, merenungkan, menelaah, meneliti atau mengkaji" yang tujuannya untuk mencerdaskan kehidupan manusia (Rumiswal \& Arham Junaidi). Menurut Abdul Kadir (2015: 8-9) Penciptaan manusia oleh Allah, maka Allah berdialog dahulu kepada Malaikat, tetapi Malaikat mempunyai pandangan yang buruk terhadap manusia. Namun, Allah memberikan pengajaran atau pendidikan kepada Malaikat bahwa penciptaan manusia adalah hanya Allah yang mengetahui tujuannya, sebagaimana terdapat dalam tafsir Alquran Surah Al-Baqarah, ayat 31. Dilihat dari wacana tentang penciptaan manusia, terlebih dahulu Allah memberikan pendidikan kepada Malaikat terhadap paradigma manusia yang nantinya diciptakan oleh Allah. Oleh karena itu, pendidikan dan manusia erat kaitannya dengan penciptaan manusia yang bersangkutan.

Pakar pendidikan, baik dari kalangan Muslim maupun Non Muslim sehingga memberikan legitimasi tentang arti pendidikan. Bagi kalangan Barat, pendidikan 
dianggap rasional yang tidak ada hubungannya dengan agama. Pendidikan dianggapnya perbedaan waktunya, antara zaman dahulu, sekarang dan akan datang. Sementara, bagi kalangan Muslim, pendidikan tidak terlepas dari "ar-rabb dengan makna pemilik, yang maha memperbaiki, yang maha pengatur, yang maha menambah, yang maha menunaikan”. Dalam buku Haidar Putra Daulay, pendidikan Islam tidak terlepas dari pandangan filsafat yang membentuk manusia yang berakhlak menurut agama Islam. Oleh karena itu, dalam agama Islam, pendidikan sangat terikat dengan hakikat materi pendidikan, yang sebagaimana agama Islam yang mengajarkan pendidikan yang tidak terlepas dari agama Islam.

Dalam konteks filsafat pendidikan, bermunculan aliran-aliran dalam pendidikan yang memiliki pandangan yang berbeda-beda tentang hakikat pendidikan. Pandangan mazhab liberal, hakikat pendidikan adalah "pemanusian manusia (humanisme)". Pandangan konservatif, pendidikan adalah sosialisasi norma atau dokrin untuk mempertahankan status quo dalam ketertiban sosial. Pandangan Perennial, pendidikan adalah warisan nilai luhur yang telah terbukti dalam sejarah. Pandangan aliran progresifisme, pendidikan adalah perubahan. Pandangan mazhab strukturalis, pendidikan adalah posisi dalam masyarakat (Tobroni dkk). Selain itu juga, pandangan psikologi tidak juga mau kalah, terhadap hakikat manusia, yang lebih menekankan kepada kegembiraan yang dialami manusia. Perbedaan paradigma terhadap hakikat pendidikan, sejak dahulu sampai sekarang menimbulkan perdebatan yang begitu hangat bagi kalangan muslim maupun non muslim. Namun, hal yang masih urgen dimiliki oleh kalangan muslim adalah sumber ilmu pengetahuan itu berasal, sehingga semakin besar perkembangan zaman maka semakin besar juga tantangan dalam pendidikan, baik dalam ruang lingkup keluarga, sekolah dan masyarakat.

Berbicara tentang hakikat isi atau materi pendidikan dalam filosofi pendidikan Islam, maka tidak terlepas dari hakikat, tugas dan fungsi, dasar dan tujuan, komponen dasar pelaksanaan, kurikulum, metode pendidikan, evaluasi dan kelembagaan Pendidikan Islam. Akan tetapi, penulis hanya menjelaskan yang berkaitan dengan hakikat manusia dan pendidikan Islam dan hakikat isi materi pendidikan yang tidak terlepas juga dari kurikulum.

\section{METODE PENELITIAN}

\section{A. Pendekatan dan Metode Penelitian}

Berdasarkan tema penelitian yang dibahas, penelitian ini digolongkan dalam jenis penelitian pustaka (library research) yaitu penelitian dengan mengambil data dari literatur yang digunakan untuk mencari konsep, teori-teori, pendapat maupun penemuan yang berhubungan erat dengan permasalahan yang diteliti.

\section{B. Sumber Data}

Sumber data berupa dokumentasi yaitu dengan cara mencari data mengenai halhal atau variabel yang berupa catatan, transkrip, buku, surat kabar, majalah dan sebagainya. 


\section{Teknik Analisis Data}

Menggunakan teknik analisis isi (content analysis) dengan jenis penyajian data deskriptif-kualitatif.

\section{HASIL DAN PEMBAHASAN}

\section{A. Hakikat Manusia dan Pendidikan Islam}

Sejak manusia diciptakan oleh Allah yang ditempatkan di bumi maka pendidikan mulai juga berlangsung. Paradigma tentang manusia berbagai macam ragam pengertiannya, baik dari pandangan barat maupun Islam. Kalau pandangan Barat, manusia berasal dari kera dengan beberapa kali mengalami evolusi sehingga terbentuklah manusia seperti sekarang ini. Namun, berbeda halnya, manusia dalam pandangan Islam. Bagi yang pernah mendapatkan kurikulum sejarah manusia, maka yang tidak tahu apa-apa kita mempercayai bahwa manusia berasal dari kera. Pendidikan adalah seumur hidup sehingga setiap jenjang pendidikan yang ditempuh sehingga paradigma tentang manusia berasal dari kera, lama-kelamaan pudar dan memunculkan paradigma baru dalam pandangan Islam, yakni manusia diciptakan oleh Allah, dengan manusia yang pertama kali meninjakkan kakinya di bumi adalah Adam dan Hawa.

Menurut Suryana dan Dadan, pandangan tentang manusia, tidaklah sebatas begitu saja, sehingga perbedaan karakteristik hewan dan manusia menjadi perbincangan yang menarik, karena manusia dan hewan, disatu sisi mempunyai kemiripan, tetapi disisi lain mempunyai perbedaan. Kemiripan tersebut digambarkan seperti orang hutan. Para ahli filosofi pun, seperti Socrates, menyebut manusia sebagai "Zoon politicon atau hewan yang bermasyarakat". Max Scheller, menyebut manusia sebagai "Das Kranke Tier atau hewan yang sakit yang selalu bermasalah dan gelisah. Selain itu juga, definisi lain tentang manusia diantaranya; Pertama, manusia adalah homo sapiens atau makhluk yang mempunyai budi. Kedua, manusia adalah homo ecomicus atau makhluk ekonomi. Ketiga, manusia adalah makhluk homo religios yakni makhluk yang beragama. Keempat, manusia adalah homo laquen atau makhluk yang pandai menciptakan bahasa dan menjelmakan pikiran dan perasaan yang tersusun dalam kata-kata (Siti Khasinah, 2013: 296-317). Pandangan filosofi-filosofi Barat tentang manusia pasti berbeda halnya dengan pandangan Islam, yang mana Islam menggambarkan perbedaan antara hewan dan manusia.

Menurut Mutahhari, perbedaan manusia dengan hewan, bukan hanya kesadarannya yang lintas ruang dan waktu, tetapi tidak terlepas dari memiliki iman dan ilmu. Prayitno, menggambarkan bahwa perbedaan manusia dan hewan adalah; Pertama, Manusia adalah makhluk yang beriman dan bertaqwa kepada Tuhan Yang Maha Esa. Kedua, Makhluk yang paling indah dan sempurna dalam penciptaan dan pencitraanya. Ketiga, Makhluk yang paling tinggi derajatnya. Keempat, Khalifah di muka bumi ini dan pemilik hak-hak asasi manusia. Manusia yang erat kaitannya dengan yang diciptakan oleh Allah, sehingga fitrah dari diri manusia adalah selalu berbuat baik sesuai dengan kodrat manusia itu diciptakan. Manusia yang bertentangan dengan kodratnya, maka dia sama juga halnya dengan binatang. 
Menurut Muhamad Mustari dan M. Taufiq Rahman, manusia pada hakikatnya terdiri dari tiga macam; (1) manusia sebagai makhluk yang bermoral yakni melakukan sesuatu sesuai norma susila yang ada, (2) manusia sebagai makhluk individual, yakni berbuat untuk kepentingan sendiri, (3) manusia sebagai makhluk sosial, yakni hidup secara bermasyarakat, bekerjasama dan saling tolong menolong. Dari ketiga hakikat manusia ini semakin berkembang dan mendapat bimbingan dan pengarahan yang benar semenjak kecil, dewasa bahkan usia lanjut.

Paradigma-paradigma yang berkaitan dengan manusia, tidak terlepas dari sumber rujukan dalam agama Islam, sehingga dimensi hakikat manusia terdiri dari; manusia sebagai hamba Allah, al-Nas, khalifah, bani adam, al-Insan dan makhluk biologis. Dalam Pancasila pun, tergambarkan hakikat manusia yang diutarakan oleh Notonegoro. Menurut Suwarno (1993: 11-14) Pada sila pertama, hakikat manusia Indosesia terhadap Tuhan, yang ditentukan oleh Tuhan, sekaligus untuk hidup taklim dan taat kepada Tuhan. Begitu juga halnya dengan sila ke dua dan seterusnya, yang tidak terlepas dari perantara Tuhan.

Dengan demikian, hakikat manusia yang telah diciptakan oleh Allah erat kaitannya dengan fitrah manusia itu sendiri, seperti halnya yang terdapat dalam hadis yang artinya, setiap manusia dilahirkan dalam keadaan fitrah, kedua orangtuanyalah yang menjadikan ia Yahudi, Nasrani maupun Majusi. Makna hadis ini, menurut penulis erat kaitannya dengan pendidikan, yang mana pendidikan adalah fitrah, tetapi yang kefitrahan tersebut akan hilang jika pendidik salah memberikan pendidikan kepada peserta didik, sehingga karakteristik yang dimiliki manusia mengakibatkan mengalami kepincangan antara karakteristik yang satu dengan yang lainnya.

Menurut Suryana dan Dadan Manusia adalah pendidikan, karena sasaran pendidikan adalah manusia. Pendidikan bermaksud untuk menumbuh kembangkan potensi yang ada pada diri manusia. Secara garis besar, pendidikan mengandung arti secara arti luas dan secara sempit, diantaranya; Pertama, Karakteristik pendidikan dalam arti luas adalah; (a) pendidikan yang berlansung sepanjang zaman, (b) pendidikan berlansung disetiap kehidupan manusia, (c) pendidikan berlangsung disegala tempat dan waktu, (d) obyek utama dari pendidikan adalah memanusiakan manusia. Kedua, Karakteristik pendidikan dalam arti sempit adalah; (a) pendidikan berlangsung dengan waktu yang terbatas, yang terlihat dari jenjang-jenjang pendidikan, (b) pendidikan berlangsung di ruang terbatas, yakni dalam lembaga pendidikan, (c) pendidikan tidak terlepas dari kurikulum dalam lembaga pendidikan, (d) isi pendidikan disusun secara sistematis dan program dalam kurikulum, (e) tujuan pendidikan terbatas oleh pihak luar sekolah (Noor Amirudin, 2018). Karakteristik manusia dalam pendidikan, erat kaitannya dengan komponen-komponen dalam pembelajaran yang tujuannya untuk pembentukan ke arah yang lebih baik.

Komponen manusia dalam pendidikan tampak dari aktualisasi dimensi kemanusiaannya, yakni dimensi fitrah, keindividualan, sosial, susila dan keberagaman yang saling keterkaitan antara satu dengan yang lainnya. Abuddin Nata, struktur fitrah manusia terdiri dari lima hal, diantaranya; Pertama, Kemampuan dasar untuk beragama Islam, yang mana faktor iman merupakan intinya dalam beribadah. Kedua, Mawahid (bakat) dan Qabliyyat (tendensi atau kecenderungan) yang mengacu pada keimanan Allah. Ketiga, Naluri dan kewahyuan yang saling terpadu dalam perkembangan manusia. Fitrah naluri berupa sifat pembawaan manusia terhadap sifat 
Allah yang menjadi potensi manusia sejak lahir, sedangkan fitrah wakyu adalah wahyu dari Allah yang diturunkan kepada nabi-nabiNya. Keempat, kemampuan dasar untuk beragama secara umum, yang tidak hanya sebatas agama Islam, tetapi terdapat juga agama-agama lain. Kelima, memiliki bakat dan kecerdasan. Dimensi dari fitrah manusia tersebut dibagi menjadi tiga bagian, yakni fitrah fisik atau jismiah/jasadiah dan fitrah psikis atau rohanian dan fitrah psikopisik atau fitrah nafsaniah (Remiswal dan Firman). Dalam agama Islam, pendidikan adalah fitrah yang mengajarkan nilai-nilai kebaikan kepada anak. Apabila, pendidikan yang diajarkan kepada anak mengandung nilai-nilai keburuan, maka fitrah pendidikan sudah kehilangan eksistensinya, sehingga mengakibatkan dimensi yang lain ikut juga mengalami kecacatan. Pendidikan itu juga, sebagai pembentukan individu manusia yang erat kaitannya dengan budaya di masyarakat sehingga tingkah laku manusia mentaati norma yang berlaku di masyarakat.

Oleh karena itu, sejak dahulu sampai sekarang, arti pendidikan tidak pernah habis-habisnya dipikirkan, baik oleh kalangan Barat maupun Islam, yang disatu sisi terdapat persamaan tetapi disisi lain terdapat perbedaan. Menurut Robert Richard Boehlke Hal yang paling urgen dari perbedaan tersebut adalah sumber pendidikan itu berasal. Untuk mengetahui sumber pendidikan tersebut, maka tidak terlepas dari hakikat pendidikan yang berdasarkan filosofi pendidikan itu sendiri yang secara urgen menjelaskan lebih mendetail tentang arti pendidikan yang sebenarnya. Dalam hal ini, untuk lebih mengetahui tentang pendidikan, maka hal yang paling utama adalah hakikat pendidikan dalam pandangan Islam.

Hakikat pendidikan Islam adalah "proses pemeliharaan dan penggunaan sifat potensi insani untuk menumbuhkan kesadaran daam menemukan kebenaran", dengan tujuan untuk meleburkan sifat dan potensi manusia kedalam sifat malakiyah. Secara umum, hakikat pendidikan dalam Islam tidak terlepas dari makna tarbiyah, ta'lim dan ta'dib. Menurut al-Nahwali, tarbiyah berasal dari tiga kata, yakni rabba-yarbu yang artinya bertambah dan tumbuh, rabiya-yarba, dengan wazan khafiya-yakhfa yang artinya menjadi besar dan rabba-yarubbu, dengan wazan madda-yamuddu, yang artinya memperbaiki, menguasai urusan, menuntut dan memelihara. Sementara, ta' lim menurut Ibn al-Manzhur adalah "mengetahui atau mengenal, mengetahui atau merasa, dan memberi kabar kepadanya (Al Rasyidin:2008). Sedangkan, ta'dib, merupakan dasar dari addaba yang artinya proses mendidik yang lebih tertuju kepada pembinaan dan penyempurnaan akhlak atau budi pekerti peserta didik. Dari beberapa pengertian tentang hakikat pendidikan Islam yang tidak terlepas dari perantara Allah, maka tugas yang diberikan oleh Allah kepada manusia adalah mendidik generasigenerasi seterusnya, baik orangtua, guru maupun tokoh-tokoh dalam masyarakat. Peran guru sangat penting dalam membentuk tingkah laku anak didik kearah positif sehingga mutu pendidikan yang ada di Indonesia ini ikut juga terangkat.

\section{B. Hakikat Materi Pendidikan Islam}

Hakikat dalam pendidikan tidak terlepas dari materi atau bahan dalam pembelajaran. Jika dilihat dari sejarah perkembangan manusia, maka materi yang menjadi bahan pembelajaran oleh manusia adalah teknologi. Teknologi mengambil 
peran yang sangat penting dalam dunia pendidikan, termasuk pendidikan dalam Islam. Oleh karena itu, untuk mengetahui hakikat dari materi dalam pendidikan maka kita menelaah lebih jauh tentang teknologi pertama kali yang dikenal oleh manusia. Piotr Sztompka, mengartikan juga bahwa perubahan yang dialami manusia tidak terlepas dari perjalanan sejarah manusia itu berlangsung, termasuk dalam hal perkembangan teknologi yang semakin membawa manfaat dan semakin membawa mudharat bagi kehidupan manusia tergantung dari manusia dalam menggunakannya, termasuk dalam bahan materi pembelajaran.

Menurut Mujiburrahman (2015), teknologi pertama kali digunakan oleh manusia adalah media tulisan tangan. Kemudian, setelah ditemukan mesin cetak sekitar tahun 1450 oleh Johan Gutenburg, maka media tulisan tangan telah tergantikan oleh mesin cetak, tetapi mengalami hambatan, karena masyarakat masih banyak yang buta huruf. Dan akhirnya, masyarakat yang mengalami buta huruf, semakin terobati dengan adanya media elektronik yakni radio. Setelah kehadiran radio, maka diikuti oleh media elektronik lainnya, seperti media televisi, telepon seluler, internet, sehingga adanya kecanggihan teknologi dan komunikasi dunia semakin berubah dan informasi semakin murah meriah. Untuk menimalisir dari dampak perkembangan teknologi tersebut, maka peran yang utama adalah pendidikan.

Menurut Edgar Morin (2005) Pendidikan adalah "kekuatan masa depan", karena pendidikan merupakan alat yang sangat ampuh untuk menghadapi keterpurukan. Pendidikan juga, sebagai salah satu alat untuk mencerdaskan bangsa sehingga pendidikan harus dikembangkan sedapat mungkin. Salah satu komponen operasional pendidikan sebagai suatu sistem adalah materi. Menurut Amirulloh Syarbini (2014) Materi pendidikan adalah "semua bahan pelajaran (pesan, informasi, pengetahuan, dan pengalaman) yang disampaikan kepada peserta didik. Materi pendidikan ini juga disebut sebagai istilah kurikulum, karena kurikulum menunjukkan makna pada materi yang disusun secara sistematis dan sekaligus untuk mencapai tujuan pendidikan yang telah ditetapkan. Hakikat dari materi pendidikan ini tidak terlepas dari kurikulum yang telah diajarkan kepada anak didik di sekolah.

Kurikulum berasal dari bahasa latin yakni "curro atau currere dan ula atau ulums, berupa kata kerja to run yang berarti lari cepat, atau menjalani, kemudian mengalami perubahan asal katanya menjadi curricula atau curriculum (Salamah :2011). Pada awalnya, kurikulum dipakai untuk berlari, kemudian dipakai juga dalam hal pendidikan, yang dimulai dari masuk sekolah sampai selesai sekolah dan ke jenjang-jenjang selanjutnya sampai ke Perguruan Tinggi.

Menurut Aslan (2017) Perubahan yang begitu pesat, sehingga kurikulum yang diajarkan di sekolah tidak mengalami keberhasilan dibandingkan kurikulum sinetron. Peran guru dalam mengajar ikut juga mengalami perubahan yang sudah beralih kepada materi dibandingkan hati sanubari. Oleh karena itu, eksistensi pendidikan saat ini ikut juga mengalami perubahan sebagaimana perkembangan teknologi, sehingga peran materi pendidikan Islam untuk mengubah pandangan guru, maka terlebih dahulu melakukan peninjauan ke arah pendidikan dahulu. 
Theodore Brameld, sebagai ahli filsafat pendidikan, bahwa pendidikan perlu dilakukan konstruksi ke arah yang lebih baik tanpa melupakan pendidikan di zaman dahulu. Materi pendidikan di zaman dahulu perlu dilakukan penataan ulang, agar tidak mengalami cultural lag pada perubahan di zaman sekarang.

Menurut Edgar Morin, materi yang sangat penting untuk menghadapi tantangan masa depan yang begitu cepat, diantaranya; Pertama, mendeteksi kekeliruan dan ilusi. Tujuan adalah penerusan bagi pengetahuan, tetapi pada kenyataanya pendidikan justru gagal menangkap realita pengetahuan manusia yang sebenarnya. Pengetahuan yang diperoleh dalam dunia pendidikan, seharusnya dapat menghadapi dari kekeliruan dalam dunia pendidikan yang selama ini semakin terpuruk. Oleh karena itu, kita harus memperkenalkan dan mengembangkan kajian dari aspek-aspek kultural, intelektual dan pengetahuan manusia, baik dari proses maupun caranya dalam memperolah ilmu pengetahuan. Kedua, Prinsip keterkaitan pengetahuan. Salah satu masalah yang begitu urgen dalam dunia pendidikan adalah mengembangkan cara belajar dengan cara menangkap masalah-masalah yang bersifat umum dan mendasar. Dominannya dalam belajar telah terbagi-bagi ke dalam berbagai disiplin ilmu yang membuat kita tidak mampu untuk menghubungkan bagian dari keseluruhan. Oleh karena itu, gaya belajar semacam ini, seharusnya diganti dengan cara belajar yang dapat memahami materi ajar sesuai dengan kontesnya dilapangan. Ketiga, mengajarkan kondisi manusiawi. Manusia adalah makhluk yang bersifat fisis, biologis, psikologis, kultural, sosial maupun historis. Oleh karena itu, kini kita tidak dapat lagi belajar apa artinya menjadi manusia tetapi manusia sebagai penghubung dari keterkaitan tersebut. Keempat, jati diri bumi. Masa depan manusia berada pada skala planet, yang selama itu terlupakan oleh pendidikan. Padahal, kita sangat membutuhkan pengetahuan dari perkembangan pendidikan dengan arus perubahan saat ini, sehingga dapat dijadikan dasar pijakan bagi pendikan. Kelima, menghadapi ketidakpastian. Perkembangan teknologi yang semakin pesat, tetapi ketidakpastian masih tetap saja ada, seharusnya ketidakpastian tersebut dapat dipecahkan oleh pendidikan. Keenam, memahami satu sama lain. Pemahaman artinya sarana dan tujuan komunikasi manusia. Oleh karena itu, pemahaman dalam memberikan pengajaran sangat penting sekaligus tugas pendidikan di masa depan. Ketujuh, etika manusia. Pendidikan harus membentuk tingkah laku ke arah positif bukan sebaliknya.

Kementerian pendidikan Nasional juga meluncurkan empat sumber dalam pendidikan untuk menghadapi tantangan zaman, yakni sumber agama, budaya, Pancasila dan tujuan pendidikan nasional. Empat sumber tersebut menghasilkan delapan belas karakter yang menjadi acuan dalam materi pembelajaran yakni, nilai religius, jujur, toleransi, disiplin, kerja keras, kreatif, mandiri, demokratis, rasa ingin tahu, semangat kebangsaan, cinta tanah air, menghargai prestasi, bersahabat/komunikatif, cinta damai, gemar membaca, peduli lingkungan, peduli sosial dan tanggung jawab.

Hakikat materi pendidikan juga, sangat melibatkan dari peran guru dalam menyampaikan materi pelajaran kepada anak didik. Guru menempati posisi kunci 
dalam dunia pendidikan. Guru merupakan sosok yang membawa pengaruh pada anak didik. Menurut Al-Zarnuji yang merupakan tokoh pendidikan klasik, menggambarkan guru haruslah menguasai materi, memiliki kematangan emosional, dan berpengetahuan. Menurut Ruslan jika dilihat dari perkembangan guru, maka kompetensi yang dimiliki oleh guru, sama halnya dengan kompetensi yang diutarakan oleh tokoh pendidikan klasik, tanpa merubah makna kompetensi guru, yang terdiri dari kompetensi profesional, pedagogik, sosial dan kepribadian seorang guru.

Keberhasilan dalam dunia pendidikan, untuk mengajarkan materi pendidikan agama Islam, maka seorang guru, harus melakukan langkah analisis isi proses untuk melakukan identifikasi, seleksi dan penetapan materi dalam pembelajaran. Proses ini dapat ditempuh dengan berpedoman kepada rambu-rambu materi yang terdapat dalam kurikulum. Disamping itu juga, dalam menganalisis materi guru, maka menggunakan pendekatan nilai moral, yang karakteristiknya meliputi pengetahuan moral, nilai moral dengan memuat pada pengenalan moral, pembiasaan moral dan pelakonan moral (Mahfud dkk:2015). Guru yang berwawasan intelektual, maka sekaligus dapat mengangkat mutu pendidikan bagi negaranya, sehingga teknologi bukan saja mengalami perkembangan tetapi membentuk tingkah laku anak didik ke arah yang postif.

Al-Gazali mengemukakan sebelas pokok kode etik peserta didik, yang seharusnya menjadi tujuan dalam pendidikan yang diberikan oleh guru, diantaranya; Pertama, belajar dengan niat ibadah dalam rangka taqarrub kepada Allah SWT, sehingga dalam kehidupan sehari-hari peserta didik dituntut untuk menyucikan jiwanya dari akhlak yang rendah dan watak yang tercela (takhalli) dan mengisi dengan akhlak yang terpuji (tahalli). Tujuan dalam hal ini, dapat dilihat dari QS.alAn'am: 162 dan Al-Dzariyat: 56. Kedua, mengurangi kecenderungan pada duniawi dibanding masalah ukhrawi (QS.ad-Dhuha: 4), artinya belajar tidak semata-mata untuk mendapatkan pekerjaan, tapi juga belajar dengan berjihad melawan kebodohan demi mencapai derajat kemanusiaan yang tinggi, baik di hadapan manusia atau Allah SWT. Ketiga, bersikap tawadlu (rendah hati) dengan cara menanggalkan kepentingan pribadi untuk untuk kepentingan pendidiknya, sekalipun cerdas, tetapi ia bijak dalam menggunakan kecerdaannya, termauk juga bijak kepada teman-temannya yang IQnya rendah. Keempat, menjaga pikiran dan pertentangan yang timbul dari berbagai aliran, sehingga ia fokus dan dapat memperoleh satu kompetensi yang utuh dan mendalam dalam belajar. Kelima, mempelajari ilmu-ilmu yang terpuji (mahmudah), baik untuk ukhrawi maupun untuk duniawi serta meninggalkan ilmu ilmu yang tercela (madzmumah). Keenam, belajar dengan bertahap atau berjenjang dengan memulai pelajaran yang mudah (konkret) menuju pelajaran yang sukar (abstrak), atau dari ilmu fardlu 'ain menuju ilmu yang fardlu kifayah. (QS.Al-Insyiqaq:19). Ketujuh, belajar ilmu sampai tuntas untuk kemudian beralih pada ilmu yang lainnya, sehingga peserta didik memiliki spesifikasi ilmu yang pengetahuan secara mendalam. (QS.AlInsyirah: 7). Kedelapan, mengenal nilai-nilai ilmiah atas ilmu pengetahuan yang dipelajari, sehingga mendatangkan objektivitas dalam memandang suatu masalah. Kedelapan, memprioritaskan ilmu diniyah yang terkait dengan kewajiban sebagai makhluk Allah SWT, sebelum memasuki ilmu duniawi. Kesembilan, mengenal nilainilai pragmatis bagi suatu ilmu pengetahuan yaitu ilmu yang bermanfaat dapat 
membahagiakan, mensejahterakan serta memberi keselamatan hidup dunia akhirat. Kesepuluh, peserta didik harus tunduk pada nasehat-nasehat pendidik (Abdul Mujib dan Jusuf Mudzakkir.: 206). Untuk menciptakan tingkah laku peserta didik, seperti yang diutarakan oleh Al-Ghazali, bukan hanya didukung dari kerjasama orangtua dan sekolah tetapi didukung juga oleh kurikulum.

Menurut Prayitno, materi pembelajaran yang menjadi keseluruhan dari kurikulum, diharapkan dapat mengorbankan energi belajar bagi peserta didik yan secara dinamik, menyuruh dan optimal, yang menyatu kedalam lima butir pokok, diantaranya; Pertama, Iman dan takwa dari unsur-unsur takwa, fitrah, kesulilaan, keberagaman. Kedua, inisiatif dari unsur daya karsa, daya rasa. Ketiga, individu dari unsur individual, daya cipta dan daya rasa. Kelima, interaksi dari unsur makhluk paling sempurna dan paling tinggi derajatnya, kesusilaan dan daya rasa. Kelima komponen ini, merupakan dasar dari hakikat materi pendidikan untuk ke arah tingkah laku yang baik dalam kehidupan sehari-hari, bermasyarakat maupun bernegara.

\section{PENUTUP}

\section{A. Simpulan}

Hakikat manusia dalam pendidikan tidak terlepas dari keberadaan dari manusia itu sendiri yang telah diciptakan oleh Allah. Manusia dan pendidikan seperti halnya dua sisi mata uang yang mana, sama-sama mempunyai nilai. Jika satunya rusak, maka nilai yang satunya juga tidak berharga. Dalam hal ini juga, pendidikan sama halnya dengan dua sisi mata uang tersebut. Nilai dari sebuah pendidikan tidak terlepas dari hakikat filosofi pendidikan yang selalu mengalami perkembangan seiring dengan perkembangan teknologi. Dari beberapa teori yang telah dikemukakan, maka hasil kajian tulisan ini, ditemukan; Pertama., hakikat manusia dan pendidikan mengalami dinamika sejarah perjalanan yang panjang sehingga kalangan Barat dan Muslim memberikan legetimasi masing-masing yang berbeda, tetapi muslim tidak terlepas dari sumber utama yakni al-Qur'an dan Hadis. Kedua, hakikat isi materi pendidikan tidak terlepas dari kurikulum dan guru yang mengajarkannya kepada peserta didik. Semakin besar dampak perubahan teknologi, maka semakin besar tantangan guru dalam dunia pendidikan. Oleh karena itu, walaupun tantangan dampak teknologi begitu besar, tetapi semangat guru mengajar dari hati tidak pernah padam dan digantikan oleh materi.

\section{B. Saran}

Teknologi sangat berperan dalam memajukan pendidikan khususnya penyampaian materi asal disertai pengawasan oleh semua pihak yaitu lembaga pendidikan, masyarakat dan orang tua. muatan isi materi pendidikan hendaknya selalu berpedoman pada nilai-nilai agama dan kurikulum pendidikan nasional supaya tercapai cita-cita bangsa ingin membentuk karakter bangsa bermartabat. 


\section{DAFTAR RUJUKAN}

Amirudin, Noor. Filsafat Pendidikan Islam: Konteks Kajian Kekinian. Caremedia Communication, 2018.

Aslan. "Kurikulum Pendidikan VS Kurikulum Sinetron." Khazanah: Studi Islam dan Humaniora 14, no. 2 (2016): 135-148.

- "Pumping Teacher dalam Tantangan Pendidikan Abad 21" 2, nomor 2 (2017): 89-100.

Aslan \& Suhari. Pembelajaran Sejarah Kebudayaan Islam. Pontianak: CV. Razka Pustaka, 2018.

Boehlke, Robert Richard. Sejarah perkembangan pikiran dan praktek pendidikan agama Kristen: Dari Yohanes Amos Comenius hingga berkembangan PAK di Indonesia. Jakarta: BPK Gunung Mulia, 1997.

Brameld, Theodore. Philosophies of Education: In Cultural Perspective. Holt, Rinehart and Winston, 1955.

Daulay, Haidar Putra. Pendidikan Islam Dalam Perspektif Filsafat. Yogyakarta: Kencana, 2014.

dkk, Mahfud. Pembelajaran Pendidikan Agama Islam Berbasis Multietnik. Yogyakarta: Deepublish, 2015.

dkk, Tobroni. Memperbincangkan Pemikiran Pendidikan Islam: Dari Idealisme Substantif Hingga Konsep Aktual. Jakarta: Kencana, 2018.

Ed, Prayitno. Dasar Teori dan Praksis Pendidikan. Indonesia: Grasindo, 2009.

Eksan, Moch. Kiai Kelana: Biografi Kiai Muchith Muzadi. Yogyakarta: PT LKiS Pelangi Aksara, 2000.

Feisal, Jusuf A. Reorientasi pendidikan Islam. Jakarta: Gema Insani Press, 1995.

Groome, Thomas H. Christian Religious Education, Terj., Daniel Stefanus. Jakarta: BPK Gunung Mulia, 2010.

Kadir, Abdul. Dasar-dasar Pendidikan. Yogyakarta: Kencana, 2015.

Kartanegara, Mulyadhi. Nalar Religius: Memahami Hakikat Tuhan, Alam, dan Manusia. Jakarta: Erlangga, 2007.

Khasinah, Siti. "Hakikat Manusia Menurut Pandangan Islam Dan Barat." Ilmiah Didaktika 13, no. 2 (2013): 296-317.

Morin, Edgar. Tujuh Materi Penting Bagi Dunia Pendidikan, Terj. Kusumastuty, Hanandyo Dardjito, Ontje Helena Manurung. Yogyakarta: Kanisius, 2005.

Mujib, Abdul, dan Jusuf Mudzakkir. Ilmu Pendidikan Islam. Jakarta: Kencana Prenada Media, 2006.

Mujiburrahman. Agama, Media Dan Imajinasi: Pandangan Sufisme Dan Ilmu Sosial Kontemporer. Cetakan 2. Banjarmasin: Antasari Press, 2015. 
Mustari, Muhamad, dan M. Taufiq Rahman. Nilai Karakter: Refleksi untuk Pendidikan Karakter. Yogyakarta: Laksbang Pressindo, 2011.

Nasional, Kementerian Pendidikan. Pengembangan Pendidikan Budaya \& Karakter Bangsa. Jakarta: Badan Penelitian dan Pengembangan Pusat Pengembangan Kurikulum, 2010.

Rasyidin, Al. Falsafah Pendidikan Islami. Bandung: Perdana Publishing, 2008.

Remiswal, dan Arham Junaidi Firman. Konsep Fitrah dalam Pendidikan Islam: Paradigma Membangun Sekolah Ramah Anak: Diandra Kreatif. Yogyakarta: Diandra Kreatif, 2018.

Ruslan. "Etiga Guru Dalam Proses Belajar Mengajar." Universitas Muhammadiyah Bima, t.t.

Salamah. Pengembangan Model Kurikulum Holistik: Pendidikan Agama Islam Pada Madrasah Tsanawiyah. Yogyakarta: Aswaja Pressindo, 2011.

Suharto. "Pengembangan Materi dan Kegiatan Pembelajarannya dalam Kurikulum Tingkat Satuan Pendidikan Bidang Seni Musik." Harmonia: Of Arts Research And Education 8, no. 3 (2007): 90-97.

Suryana, dan Dadan. Pendidikan Anak Usia Dini (Teori dan Praktik Pembelajaran. Padang: UNP Press, 2013.

Sutrisno, Aliet Noorhayati. Telaah Filsafat Pendidikan. Yogyakarta: Deepublish, 2014.

Suwarno, P. J. Pancasila budaya bangsa Indonesia: penelitian Pancasila dengan pendekatan, historis, filosofis \& sosio-yuridis kenegaraan. Yogyakarta: Kanisius, 1993.

Syarbini, Amirulloh. Model Pendidikan Karakter Dalam Keluarga. Jakarta: Elex Media Komputindo, 2014.

Sztompka, Piotr. Sociology Of Social Change. Cambridge USA: Oxford UK, 1993.

Wade, Carole, dan Carol Tavris. Psikologi, Edisi 9, jilid 1. Indonesia: Erlangga, t.t. 